\title{
HUBUNGAN KEGIATAN EKSTRAKURIKULER DENGAN MOTIVASI BELAJAR DAN PRESTASI BELAJAR SISWA DI KELAS XI MAN 2 KABUPATEN CIREBON
}

\author{
Mukhlisin' $^{1}$, Cecep Sumarna ${ }^{2}$ \\ IAIN Syekh Nurjati Cirebon ${ }^{1,2}$ \\ ziz.mukhlisin@yahoo.com; cecepsumarna71@gmail.com
}

\begin{abstract}
Abstrak
Kegiatan ektrakurikuler merupakan kegiatan kurikuler yang dilaksanakan sekolah di luar jam kegiatan intrakurikuler dan kokurikuler. Tujuannya adalah mengembangkan potensi, bakat, minat, kemampuan siswa. Harapannya siswa yang mengikuti ektrakurikuler dapat menjadi siswa yang mempunyai kompetensi yang lebih. Namun kegiatan ekstrakurikuler terkadang dijadikan sebab siswa di sekolah tersandung masalah dalam proses kegiatan belajar. Penelitian ini bertujuan untuk mengetahuai bagaimana motivasi belajar siswa dan juga prestasi belajar siswa kelas XI MAN 2 Kab. Cirebon yang mengikuti kegiatan ektrakurikuler dan bagaimana hubungan kegiatan ektrakurikuler dengan motivasi belajar dan prestasi belajar siswa. Pendekatan dalam penelitian ini menggunakan pendekatan kuantitatif, teknik pengumpulan data melalui angket dan hasil nilai rapot. Teknik analisis yang digunakan yaitu korelasi product moment dan korelasi sederhana. Rekapitulasi rata- rata hasil angket mengenai kegiatan ektrakurikuler, diperoleh nilai 87, $5 \%$ termasuk dalam kategori baik. Kemudian rekapitulasi rata-rata hasil angket mengenai motivasi belajar siswa, diperoleh nilai 78, 75 \% dan termasuk dalam kategori baik. Berdasarkan rekapitulasi rata-rata hasil nilai rapot mengenai prestasi belajar siswa, diperoleh nilai 94, 4 \% dan termasuk dalam kategori baik. Hasil pearson correlation antara kegiatan ekstrakurikuler dengan motivasi belajar siswa sebesar 0,641 dengan Sig. 0,000 $<0,05$. Artinya terdapat hubungan yang positif antara kegiatan ekstrakurikuler dengan motivasi belajar siswa dan nilai hubungannya adalah kuat karena 0,641 nilai korelasi ini berada di interval 0,60-0,80. Hasil pearson correlation antara kegiatan ekstrakurikuler dengan prestasi belajar siswa sebesar 0,649 dengan Sig. 0,000<0,05. Artinya terdapat hubungan yang positif antara kegiatan ekstrakurikuler dengan motivasi belajar siswa dan nilai hubungannya adalah kuat karena0,649 nilai korelasi ini berada di interval 0,600,80 .
\end{abstract}

Kata Kunci: Kegiatan Ekstrakurikuler, Motivasi Belajar Siswa, Prestasi Belajar Siswa

\begin{abstract}
Extracurricular activities are curricular activities conducted outside school hours of intracurricular and cocurricular activities. The goal is to develop the potential, talent, interest, and ability of students. The hope that students who
\end{abstract}


follow extracurricular can become students who have more competence. But extracurricular activities are sometimes used as the students at school stumble into problems in the learning process. This study aims to know how the students' learning motivation and also student achievement class XI MAN 2 Kab. Cirebon who follow extracurricular activities and how the relationship ektrakurikuler activities with learning motivation and student achievement. The approach in this study using quantitative approach, data collection techniques through questionnaires and the results of rapot. The analysis technique used is the product moment correlation and simple correlation. Recapitulation of average questionnaire results about extracurricular activities, obtained value 87, $5 \%$ included in either category. Then the recapitulation of the average questionnaire on student learning motivation, obtained value $78,75 \%$ and included in either category. Based on the average recapitulation of the results of rapot score on student achievement, obtained 94\%, 4\% and included in either category. Results of pearson correlation between extracurricular activities with student learning motivation of 0.641 with Sig. 0,000 <0.05. This means there is a positive relationship between extracurricular activities with student learning motivation and the value of the relationship is strong because 0.641 correlation value is in the interval from 0.60 to 0.80 . Results of pearson correlation between extracurricular activities with student achievement of 0.649 with Sig. 0,000 $<0.05$. This means there is a positive relationship between extracurricular activities with student learning motivation and the value of the relationship is strong because 0.649 this correlation value is in the interval from 0.60 to 0.80 .

Keywords: Extracurricular Activities, Student Motivation, Student Achievement

\section{A. PENDAHULUAN}

1. Latar Belakang Masalah

Undang-Undang No. 20 Tahun 2003 tentang Sistem Pendidikan Nasional dalam Bab II pasal 3 menerangkan Pendidikan Nasional berfungsi mengembangkan kemampuan dan membentuk watak serta peradaban bangsa yang bermartabat dalam rangka mencerdaskan kehidupan bangsa, bertujuan untuk berkembangnya potensi siswa agar menjadi manusia yang beriman dan bertakwa kepada Tuhan Yang Maha Esa, berakhlak mulia, sehat, berilmu, cakap, kreatif, mandiri, dan menjadi warga negara yang demokratis serta tanggung jawab. Kegiatan pendidikan bertujuan bukan hanya untuk mencerdaskan peserta didiknya, namun juga harus sampai kepada pengembangan terhadap segela potensi yang dimiliki oleh para peserta didik. 
Sekolah sebagai lembaga pendidikan merupakan tempat berlangsungnya proses belajar dan pembelajaran. Selain itu, sekolah juga merupakan wadah melakukan upaya-upaya dalam mengembangkan potensi yang dimiliki para siswanya. Kegiatan ekstrakurikuler merupakan bentuk dari upaya pengembangan diri siswa di luar dari progam pembelajaran. Kegiatan ekstrakurikuler diselenggarakan sebagai wadah bagi siswa disesuaikan dengan minat, bakat dan kebutuhan peserta didik. Menurut Yuda dalam Hardianus (2014: 4-5) ekstrakurikuler bertujuan untuk memberikan sumbangan pada perkembangan kepribadian peserta didik, khususnya bagi mereka yang ikut berpartisipasi. Sedangkan menurut Cahyandaru (2013: 2) kegiatan ekstrakurikuler merupakan pelengkap dari kurikulum, yang dalam pelaksanaannya setiap siswa diberi kebebasan untuk memilih kegiatan sesuai dengan minat dan bakatnya.

MAN 2 Kabupaten Cirebon adalah salah satu sekolah yang memfasilitasi peserta didiknya dengan beragam ekstrakurikuler terdiri dari Pramuka, PMR, Paskibra, MBD (Majlis Bimbingan Dakwa), PKS, KIR, PA, Seni dan Teater, Jurnalis, dan Kopsis.

Kegiatan ekstrakurikuler yang ada di MAN 2 Kabupaten Cirebon memiliki kegiatan yang aktif. Peran pembina dan juga penggiat ektrakurikuler tidak terlepas dalam aktifnya segala kegiatan yang ada. Akan tetapi aktifnya para siswa di kegiatan ekstrakurikuler mengakibatkan terbaginya perhatian dan fokus sebagai siswa memiliki kewajiban belajar di kelas dengan anggota ektrakurikuler berkewajiban aktif dalam kegiatan di ektrakurikuler. Sehingga apabila siswa tidak dapat mengatur waktu dan prioritas maka akan timbul masalah baik dalam proses belajar ataupun pada kegiatan ekstrakurikuler.

Hj. Endang Hartati (8/12/2017) pembina esktrakurikuler kesenian menerangkan dalam sebuah wawancara bersama peneliti bahwa sebuah situasi tidak diinginkan terjadi salah satu aktifis ekstrakurikuler yang juga menjadi Ketua OSIS tidak naik kelas. Hal ini terjadi disebabkan karena siswa tersebut jarang hadir dalam pembelajaran di kelas dan mengakibatkan nilai rapotnya pun buruk. Dadang Daud (5/2/2018) 
pembina ektrakurikuler PKS memberikan pendapat bahwa beberapa siswa yang mengikuti kegiatan ektrakurikuler dan kemudian menjabat kepengurusan memang terkadang menjadi lupa kewajiban utama di sekolah yaitu belajar di kelas.

Dengan masalah yang diterangkan diatas, bahwa kegiatan ektrakurikuler belum maksial dimanfaatkan semestinya oleh beberapa siswa di MAN 2 Kabupaten Cirebon khususnya kelas XI yang menjabat kepengurusan. Terganggunya waktu belajar beberapa siswa yang mengikuti kegiatan ekstrakurikuler, kegiatan ekstrakurikuler menjadi alasan beberapa siswa untuk tidak mengikuti belajar di kelas, dan juga menurunnya prestasi belajar beberapa siswa yang mengikuti kegiatan ektrakurikuler. Dengan masalah tersebut peneliti tertarik untuk meneliti dengan mengangkat judul penelitian tentang "Hubungan Kegiatan Ekstrakurikuler dengan Motivasi Belajar dan Prestasi Belajar Siswa di Kelas XI MAN 2 Cirebon”.

2. Rumusan Masalah

Berdasarkan pembatasan masalah di atas, maka rumusan masalah dalam penelitian ini adalah sebagai berikit:

a. Bagaimana kegiatan ektrakurikuler di Kelas XI MAN 2 Kabupaten Cirebon?

b. Bagaimana motivasi belajar siswa di Kelas XI MAN 2 Kabupaten Cirebon?

c. Bagaimana prestasi belajar siswa di Kelas XI MAN 2 Kabupaten Cirebon?

d. Bagaimana hubungan kegiatan ekstrakurikuler dengan prestasi belajar siswa di Kelas XI MAN 2 Kabupaten Cirebon?

e. Bagaimana hubungan kegiatan ekstrakurikuler dengan prestasi belajar siswa di Kelas XI MAN 2 Kabupaten Cirebon?

3. Tujuan Penelitian

Adapun tujuan dari penelitian ini adalah sebagai berikut:

a. Mengetahui kegiatan ektrakurikuler di Kelas XI MAN 2 Kabupaten Cirebon. 
b. Mengetahui motivasi belajar siswa di Kelas XI MAN 2 Kabupaten Cirebon.

c. Mengetahui prestasi belajar siswa di Kelas XI MAN 2 Kabupaten Cirebon.

d. Mengetahui hubunga kegiatan ektrakurikuler dengan motivasi belajar siswa di Kelas XI MAN 2 Kabupaten Cirebon.

e. Mengetahui hubunga kegiatan ektrakurikuler dengan prestasi belajar siswa di Kelas XI MAN 2 Kabupaten Cirebon.

\section{B. KAJIAN TEORI}

1. Kegiatan Ekstrakurikuler

Menurut Peraturan Menteri Pendidikan dan Kebudayaan Republik Indonesia Nomor 62 Tahun 2014 Pasa 1 ayat 1 bahwa kegiatan ekstrakurikuler adalah kegiatan kurikuler yang dilakukan peserta didik di luar jam belajar kegiatan intrakurikuler dan kegiatan kokurikuler, dibawah bimbingan dan pengawasan satuan pendidikan. Menurut Rohina (2012: 75) kegiatan ektrakurikuler adalah suatu kegiatan atau aktivitas di luar mata pelajaran dan pelayanan konseling untuk membantu mengembangkan peserta didik sesuai dengan kebutuhan, potensi, bakat, dan minat mereka.

Menurut Suryobroto dalam Cahyandaru (2013: 12) kegiatan ekstrakurikuler memiliki tujuan diantaranya pertama, dapat meningkatkan kemampuan siswa dalam aspek kognitif, afektif dan psikomotorik. Kedua, mengembangkan minat dan bakat siswa dalam upaya pembinaan kepribadian menuju pembinaan manusia seutunya yang posistif. Ketiga, dapat mengetahui, mengenal serta membedakan antara hubungan satu pelajaran dengan pelajaran lainnya.

2. Motivasi Belajar Siswa

Menurut Menurut Donald dalam Kompri (2015: 229) motivasi adalah suatu perubahan energi di dalam pribadi seseorang yang ditandai dengan perasaan dan reaksi untuk mencapai tujuan. Menurut Suhana (2014: 24) motivasi belajar siswa merupakan kekuatan (power motivation), daya dorong (driving force), atau alat pembangun kesediaan dan keinginan yang kuat 
dalam diri siswa untuk belajar secara aktif, kreatif, efektif, inovatif dan menyenagkan dalam rangkah perubahan perilaku menjadi lebih baik dalam aspek kignitif, afektif, psikomotorik. Menurut Soemanto dalam Kompri (2015: 226) ada tiga faktor yang mempengaruhi motivasi belajar yaitu pertama Faktor stimuli, kedua Faktor metode belajar, ketiga Faktor individual.

\section{Prestasi Belajar Siswa}

Prestasi belajar merupakan bagian terpenting dalam pembelajaran. Gagne menyebutkan dalam Dimyati dan Mudjiono (2013: 10) prestasi belajar yaitu penguasaan terhadap empat aspek belajar yaitu keterampilan, pengetahuan, sikap, dan nilai. Sedangkan menurut Winkel dalam Purwanto (2016: 45) menjelaskan prestasi belajar merupakan transformasi pada sikap dan perilaku manusia yang mengacu pada taksonomi tujuan pengajaran yang mencangkup aspek kognitif, afektif, dan psikomotorik.

Diantara Taksonomi Bloom mengemukakan bahwa perbuahan sebagai prestasi belajar meliputi domain-domain yaitu:

a. Kognitif meliputi perubahan-perubahan dalam segi penguasaan pengetahuan dan perkembangan keterampilan.

b. Afektif meliputi perubahan-perubahan dari segi material, perasaan dan kesadaran.

c. Psikomotorik meliputi perubahan-perubahan dari segi bentuk-bentuk tindakan motorik (Syaiful, 2006: 33).

Menurut Frandsen dalam Sardiman (2016: 46) faktor yang mendorong dan mempengaruhi prestasi belajar ada enam faktor diantaranya, pertama, adanya sifat ingin tahu dari dalam diri. Kedua, adanya sifat yang kreatif dan ingin maju. Ketiga, adanya keinginan untuk mendapatkan simpati dari orang tua, guru, ataupun teman. Keempat, adanya keinginan untuk memperbaiki kegagalan yang lalu dengan usaha yang lebih baik. Kelima, adanya keinginan untuk mendapatkan rasa aman jika dapat menguasai pelajaran. Keenam, adanya ganjaran (reward) atau hukuman (punishment) sebagai akhir dari belajar. 
4. Kajian Penelitian yang Relevan

Hasil penelitian yang telah dilakukan oleh Defri Hardianus, 2014. Hubungan Kegiatan Ektrakulikuler dengan Prestasi Belajar Siswa SMK Perindustrian Yogyakarta. (Yogyakarta: Fakultas Teknik Universitas Negeri Yogyakarta).

Berdasarkan peneliatian diperoleh data sebagai berikut. Terdapat hubungan positif terbukti harga $r_{\text {hitung }} 0,410>r_{\text {tabel }}=0,349$ dan dapat disimpulkan bahwa ada hubungan yang positif antara kegiatan ekstrakurikuler dengan prestasi belajar siswa SMK Perindustrian Yogyakarta.

\section{METODE PENELITIAN}

1. Jenis Penelitian

Metode dalam penelitian ini adalah metode penelitian kuantitatif.

2. Lokasi dan Waktu Penelitian

Penelitian ini dilakukan di Kelas XI MAN 2 Kabupaten Cirebon. Adapun pelaksanaan penelitian dari tanggal 5 Desember 2017 sampai dengan 5 Februari 2018.

3. Teknik Pengumpulan Data

a. Wawancara

Wawancara yaitu teknik pengumpulan data yang digunakan untuk lebih mendalami responden secara spesifik yang dapat dilakukan dengan tatap muka ataupun komunikasi menggunakan alat bantu komunikasi.

(Sugiono, 2013:194).

b. Angket

Menurut Sugiono (2013: 162), angket adalah teknik pengumpulan data yang dilakukan dengan cara member seperangkat pertanyaan atau pernyataan tertulis kepada responden untuk dijawabnya. Tujuan penyebaran angket ini adalah untuk mendapatkan data objektif yang berkaitan dengan pengaruh kecerdasan emosional remaja terhadap perilakunya. 


\section{c. Studi dokumentasi}

Menurut Noor (2011: 141) studi dokumentasi adalah sejumlah besar fakta dan data tersimpan dalam bahan yang berbentuk dokumentasi. Sebagian data yang tersedia yaitu berbentuk surat, catatan harian, cendera mata, laporan, artefak, foto, autobiografi, surat pribadi, buku atau catatan harian, memorial, kliping, dokumen pemerintah atau swasta, data di server dan flashdisk, dan data yang tersimpan di website

4. Teknik Analisis Data

a. Skala Prosentase

$$
\mathrm{P}=\frac{F}{N} \times 100 \%
$$

Keterangan:

$\mathrm{P} \quad=$ Angka presentasi (jumlah yang diharapkan)

$\mathrm{F} \quad=$ Alternatif jawaban (Frekuensi yang dicari)

$\mathrm{N} \quad=$ Number of case (jumlah frekuensi/ banyaknya Individu)

b. Korelasi Product Moment

(Anas Sudijono, 2006)

Koefisien korelasi sederhana menunjukan seberapa besar hubungan yang terjadi antara dua variable dengan penafsiran sebagai berikut:

Antara 0,00-0,20 : Korelasi sangat rendah

Antara 0,2-0,40 : Korelasi yang sangat lemah

Antara 0,40-0,60 : Korelasi yang sedang dan cukup

Antara 0,60-0,80 : Korelasi sangan tinggi

Antara 0,80-1,00 : Korelasi yang sangat tinggi

(Suharsimi, $2006: 213$ )

\section{HASIL PENELITIAN DAN PEMBAHASAN}

Penelitian ini dilakukan untuk mengetahui bagaimana hubungan kegiatan ekstrakurikuler dengan motivasi dan prestasi belajar siswa kelas XI MAN 2 Kabupaten Cirebon.

Besarnya korelasi (person correlation) antara Nilai korelasi antara kegiatan ektrakurikuler dengan motivasi belajar siswa adalah 0,641. Dan nilai 0,641 ini berada pada kisaran 0,60-0,80 maka hubungannya adalah kuat. Artinya hubungan kegiatan ekstrakurikuler dengan motivasi belajar 
siswa adalah kuat dengan arah hubungan yang positif. Dan nilai sig. 0,000< 0,05. Maka dapat disimpulkan bahwa terdapat hubungan yang positif antara kegiatan ektrakurikuler dengan motivasi belajar siswa.

Kegiatan ekstrakurikuler menurut Rohinah (2012: 94) diselenggarakan oleh sekolah dengan tujuan untuk menyalurkan minat dan bakat siswa agar dapat terasah keterampilan dan/soft skill siswa baik dalam bidang kesenian, olahraga, agama, bahasa, dan lain-lain. Menurut Muahaimin (2008: 74) kegiatan ekstrakurikuler merupakan kegiatan pendidikan yang dilaksanakan di luar jam pelajaran intrakurikuler di kelas dan pelayanan konseling yang bertujuan untuk membantu mengembangkan kemampuan peserta didik sesuai dengan kebutuhan, potensi, bakat dan minat melalui kegiatan yang secara khusus diselenggarakan oleh pendidik atau tenaga kependidikan yang berkewenangan atau berkemampuan di sekolah atau madrasah.

Menurut Donald dalam Kompri (2015: 229) motivasi adalah suatu perubahan energi di dalam pribadi seseorang yang ditandai dengan perasaan dan reaksi untuk mencapai tujuan. Dari pendapat Donald motivasi timbul karena adanya tujuan yang ingin dicapai, dan orang yang mempunyai tujuan dalam sebuah tindakan maka ia akan memiliki dorongan dengan segala bentuk upaya untuk dapat menggapai tujuannya tersebut.

Sedangkan Menurut Suhana (2014: 24) motivasi belajar siswa merupakan kekuatan (power motivation), daya dorong (driving force), atau alat pembangun kesediaan dan keinginan yang kuat dalam diri siswa untuk belajar secara aktif, kreatif, efektif, inovatif dan menyenagkan dalam rangkah perubahan perilaku menjadi lebih baik dalam aspek kignitif, afektif, psikomotorik.

Berdasarkan uaraian di atas dapat dijelaskan bahwa kegiatan ekstrakurikuler dengan motivasi belajar siswa mempunyai hubungan. Karena kegiatan ektrakurikuler bertujuan untuk mengembangkan kemampuan diri siswa yang diselenggarakan oleh sekolah. Apabila kegiatan ekstrakurikuler dapat dimaksimalkan dengan baik maka motivasi belajar siswa pun dapat menjadi lebih baik. Hal ini terjadi karena timbulnya motivasi belajar siswa dapat terjadi salah satu sebabnya karena kemampuan 
diri yang dimiliki siswa mengemumpuni. Sehingga pengalaman, skill, dan pengetahuan yang didapatkan dari kegiatan ekstrakurikuler adalah sebagai modal kepercayaan diri untuk dapat menacapai tujuan yang diinginkan.

Besarnya korelasi (person correlation) antara Nilai korelasi antara kegiatan ektrakurikuler dengan prestasi belajar siswa adalah 0,649. Dan nilai 0,649 ini berada pada kisaran 0,60 sampai dengan 0,80 maka hubungannya adalah kuat. Artinya hubungan kegiatan ekstrakurikuler dengan motivasi belajar siswa adalah kuat dengan arah hubungan yang positif. Dan nilai sig. 0,000<0,05. Maka dapat disimpulkan bahwa terdapat hubungan yang positif antara kegiatan ektrakurikuler dengan motivasi belajar siswa.

Dalam Peraturan Menteri Pendidikan dan Kebudayaan Republik Indonesia Nomor 62 Tahun 2014 Pasal 2 menerangkan kegiatan ekstrakurikuler diselenggarakan dengan tujuan untuk mengembangkan potensi, bakat, minat, kemampuan, kepribadian, kerjasama, dan kemandirian peserta didiksecara optimal dalam rangka mendukung pencapaian tujuan pendidikan nasional. Sedangkan Suryobroto dalam Cahyandaru (2013: 12) menjelaskan kegiatan ekstrakurikuler memiliki tujuan diantaranya pertama, dapat meningkatkan kemampuan siswa dalam aspek kognitif, afektif dan psikomotorik. Kedua, mengembangkan minat dan bakat siswa dalam upaya pembinaan kepribadian menuju pembinaan manusia seutunya yang posistif. Ketiga, dapat mengetahui, mengenal serta membedakan antara hubungan satu pelajaran dengan pelajaran lainnya.

Gagne menyebutkan dalam Dimyati dan Mudjiono (2013: 10) prestasi belajar yaitu penguasaan terhadap empat aspek belajar yaitu keterampilan, pengetahuan, sikap, dan nilai.

Sedangkan menurut Winkel dalam Purwanto (2016: 45) menjelaskan prestasi belajar merupakan transformasi pada sikap dan perilaku manusia yang mengacu pada taksonomi tujuan pengajaran yang mencangkup aspek kognitif, afektif, dan psikomotorik.

Prestasi belajar merupakan penguasaan terhadap apa yang telah dipelajari. Syah (2008: 132) membagi prestasi belajar menjadi tiga bagian yaitu, pertama, prestasi belajar dalam bentuk pengetahuan dan pengertian. hal 
ini meliputi ingatan, pemahaman, penegasan, sintesa, analisa dan evaluasi. Kedua, prestasi belajar dalam bentuk keterampilan intelektual dan keterampilan sosial. Ketiga, prestasi belajar dalam bentuk sikap atau nilai. berdasarkan pengertian prestasi belajar di atas dapat dipahami bahwa prestasi belajar adalah kemampuan- kemampuan yang dimiliki siswa setelah menerima pengalaman belajar. Kemampuan-kemampuan tersebut mencangkup aspek kognitif, afektif, dan psikomotorik.

Berdasarkan uaraian di atas dapat dijelaskan bahwa kegiatan ekstrakurikuler dengan prestasi belajar siswa mempunyai hubungan. Kegiatan ekstrakurikuler merupakan kegiatan tambahan yang dilaksanakan diluar aktifitas kegiatan intrakurikuler dan kokurikuler yang tujuannya adalah untuk mengasah kemampuan-kemampuan yang dimiliki siswa melalui bentukbentuk kegiatan ekstrakurikuler yang beragam sesuai dengan minat dan keinginan siswa. Selain itu kegiatan ekstrakurikuler juga dengan segala bentuk kegiatan yang beragam menjadikan siswa memiliki tambahan pengetahuan, sikap, dan keterampilan. Kemampuan-kemampuan yang sudah diasah, dikembangkan, dan dibangun melalui kegiatan ekstrakurikuler akan memiliki kontribusi lebih bagi siswa dalam proses pembelajaran di kelas untuk dapat menunjang prestasi belajar siswa mencangkup ketiga aspek tersebut yaitu kognitif, afektif, psikomotorik menjadi lebih baik.

\section{E. SIMPULAN DAN SARAN}

1. Simpulan

Setelah melakukan penelitian di lapangan dan menganalisis hasil penelitian, penulis mengambil kesimpulan sebagai berikut:

a. Kegiatan Ektrakurikuler Kelas XI MAN 2 Kab. Cirebon. Berdasarkan rekapitulasi rata-rata hasil angket variabel $\mathrm{X}$ mengenai kegiatan ektrakurikuler kelas XI MAN 2 Kab. Cirebon, maka dapat diambil kesimpulan bahwa kegiatan ekstrakurikuler termasuk dalam kategori baik, dengan nilai 87, 5 \% karena berada pada interval 75-100\%.

b. Motivasi Belajar Siswa Kelas XI MAN 2 Kab. Cirebon. Berdasarkan rekapitulasi rata-rata hasil angket variabel Y1 mengenai motivasi belajar 
siswa kelas XI MAN 2 Kab. Cirebon, maka dapat diambil kesimpulan bahwa motivasi belajar siswa termasuk dalam kategori baik, dengan nilai 78, 75 \% karena berada pada interval 75-100\%.

c. Prestasi Belajar Siswa Kelas XI MAN 2 Kab. Cirebon. Berdasarkan rekapitulasi rata-rata hasil rapot siswa variabel Y2 mengenai prestasi belajar siswa kelas XI MAN 2 Kab. Cirebon, maka dapat diambil kesimpulan bahwa prestasi belajar siswa termasuk dalam kategori baik, dengan nilai 94, 4 \% karena berada pada interval 76-100\%.

d. Hubungan kegiatan ekstrakurikuler dengan motivasi belajar siswa kelas XI di MAN 2 Kab. Cirebon. Besarnya korelasi (person correlation) antara Nilai korelasi antara kegiatan ektrakurikuler dengan motivasi belajar siswa adalah 0,641. Dan nilai 0,641 ini berada pada kisaran 0,60-0,80 maka hubungannya adalah kuat. Artinya hubungan kegiatan ekstrakurikuler dengan motivasi belajar siswa adalah kuat dengan arah hubungan yang positif. Dan nilai sig. 0,000 < 0,05. Maka dapat disimpulkan bahwa terdapat hubungan yang positif antara kegiatan ektrakurikuler dengan motivasi belajar siswa.

e. Hubungan kegiatan ekstrakurikuler dengan prestasi belajar siswa kelas XI di MAN 2 Kab. Cirebon. Besarnya korelasi (person correlation) antara Nilai korelasi antara kegiatan ektrakurikuler dengan prestasi belajar siswa adalah 0,649. Dan nilai 0,649 ini berada pada kisaran 0,60 sampai dengan 0,80 maka hubungannya adalah kuat. Artinya hubungan kegiatan ekstrakurikuler dengan motivasi belajar siswa adalah kuat dengan arah hubungan yang positif. Dan nilai sig. 0,000<0,05. Maka dapat disimpulkan bahwa terdapat hubungan yang positif antara kegiatan ektrakurikuler dengan motivasi belajar siswa.

2. Saran

Berdasarkan kesimpulan yang penulis uraikan diatas, maka penulis mengajukan beberapa saran guna perkembangan selanjutnya kearah yang lebih baik: 
a. Bagi peneliti selanjutnya

Disarankan untuk peneliti selanjutnya jika meneliti variabel yang sama, gunakan instrument tambahan dalam proses penelitian berupa observasi sistematis untuk lebih mendalami setiap variabel.

b. Bagi siswa

Disarankan bagi siswa untuk memanfaatkan segala kegiatan ekstrakurikuler dengan sebaik-baiknya. Dan belajar di kelas merupakan prioritas dan jadikan kegiatan ekstrakurikuler sebagai kegiatan pendukung untuk menambah pengetahuan, keterampilan, dan juga pengalaman berorganisasi.

c. Bagi guru dan sekolah

Disarankan supaya guru dan sekolah khususnya para pembina untuk bersama-sama mengawasi, membimbing, dan memberikan arahan terhadap para siswa yang mengikuti kegiatan ekstrakurikuler khususnya pada tiap kegiatan rutin yang dilakukan setiap hari jumat. Kemudian agar kegiatan ekstrakurikuler di MAN 2 Kab. Cirebon menjadi lebih baik, peneliti memberikan masukan supaya jam mulai dan selesai kegiatan ektrakurikuler ditentukan agar kegiatan yang dilakukan dapat terjadwal dengan baik. Serta dibuatkan kartu tanda anggota ekstrakurikuler sebagai tanda siswa tersebut adalah aktifis ekstrakurikuler.

\section{DAFTAR PUSTAKA}

Arikunto, Suharsimi. 2006. Prosedur Penelitian Suatu Pnedekatan Praktik. Jakarta: Rineke Cipta.

Cahyandaru, Handoko. 2013. Pengaruh keaktifan siswa dalam ekstrakurikuler terhadap prestasi belajar siswa kelas XI MAN Jogjakarta. Jogjakarta: UNY.

Cucu, Suhana. 2014. Konsep Strategi Pembelajaran. Bandung : Revika Aditama.

Dimyati dan Mudjiono. 2013. Belajar dan Pembelajaran. Jakarta: Rineka Cipta.

Hardinus, Defri. 2014. Hubungan kegiatan ekstrakurikuler dengan prestasi belajar siswa SMK Perindustrian Jogjakarta. Jogjakrta: UNY. 
Kompri. 2015. Motivasi Pembelajaran Presprektif Guru dan Siswa. Bandung: Remaja Rosdakarya.

Muhaimin. Dkk. 2008. Pengembangan Model KTSP pada Sekolah dan Madrasah. Jakarta: Raja Grapindo Persada.

Noor, Juliansyah. 2011. Metodologi Penelitian. Jakarta : Kencana Prenada Media Group.

Peraturan Menteri Pendidikan dan Kebudayaan Republik Indonesia Nomor 62 Tahun 2014 Pasa 1 ayat 1.

Purwanto, M. Ngalim. 2016. Psikologi Pendidikan. Bandung: Remaja.

Rosdakarya. Noor, Rohinah M. 2012. The Hidden Curriculum Membangun Karakter Melalui Kegiatan Ekstrakurikuler. Yogyakarta: Pedagogia.

Sardiman. 2012. Interaksi dan Motivasi Belajar Mengajar. Jakarta: Raja Grafindo Persada.

Sagala, Syaiful. 2006. Konsep Dan Makna Pembelajaran. Bandung: Alfabeta.

Sudijono, Anas. 2006. Pengantar Statistik Pendidikan. Jakarta: Raja Grafindo Persada.

Sugiyono. 2013. Metode Penelitian Pendidikan: Pendekatan Kuantitatif, Kualitatif, dan $R \& D$. Bandung: Alfabeta.

Undang-Undang No. 20 Tahun 2003 tentang Sistem Pendidikan Nasional dalam Bab II pasal 3. 